\title{
Fokus „der Wilde Westen 2016“ - Teil1
}

Ultraschall Journal Club by Hannes Gruber und Andrea Klauser. Die beiden aktuell wissenschaftlich maßgeblichen Arbeitsgruppen in Westösterreich waren im Jahr 2016 nicht untätig; hier wird zum ersten Mal Exemplarisches zur (klinisch-) sonografischen Forschung präsentiert - interessante Publikationen werden in diesem Rahmen zur Kenntnis gebracht („Was? Das kann man sonografisch feststellen?") bzw. thematisch eingeordnet („Das hilft das Problem zu lösen!“); diese Auflistung ersetzt (bei weitergehendem Interesse) allerdings das entsprechende Literaturstudium nicht sondern soll auf jeden Fall „Appetit“ machen ...

\section{Arbeitsgruppe Gruber}

- Rofo. 2015 Nov;187(11):998 - 1002. doi: $10.1055 /$ s-0035 - 1553 221. Epub 2015 Jun 19.

The Ulnar Nerve After Surgical Transposition: Can Sonography Define the Reason of Persisting Neuropathy? Gruber, Baur E, Plaikner, Loizides

Die therapeutische Verlagerung des Nervus ulnaris aus seiner Grube am Ellbogen ist leider immer noch eine chirurgische Option, allerdings mit oft schlechter Prognose: in dieser Arbeit konnten die Autoren die postoperative Situation des verlagerten
Nervus ulnaris darstellen und die durch die therapeutisch versuchte Verlagerung provozierten pathologischen Veränderungen aufzeigen: es kommt derzeit zu einem Paradigmenwechsel besonders zur operativen Verlagerung von pathologischen Nervensegmenten.

- Rofo. 2016 Sep 19. [Epub ahead of print] Memory Effect of the Median Nerve: Can Ultrasound Reliably Depict Carpal Tunnel Release Success? Steinkohl F, Gruber L, Gruber H, Löscher W, Glodny B, Pülzl P, Baur E, Loizides.

Macht es Sinn Nervi mediani nach KarpalTummel-Release zu kontrollieren? Gibt es sonografische Features, die uns eine erfolgreiche Therapie nachweisen? Diese Arbeit zeigt uns, dass es die nicht gibt! Der strangulierte Nerv unterliegt einem inneren Umbau welcher sich durch die karpale Bandspaltung nicht mehr rückgängig machen lässt; diesen „memory effect“ gilt es besonders auch im Falle eines Rezidives zu berücksichtigen!

- AJR Am J Roentgenol. 2016 Dec 13:1 - 9. [Epub ahead of print]

Soft-Tissue Tumor Contrast Enhancement Patterns: Diagnostic Value and Comparison Between Ultrasound and MRI. Gruber, Loizides A, Luger A, Glodny B, Moser P, Henninger, Gruber H.
Weichteiltumoren sind selten, die meisten sind Lipome, warum sind sie trotzdem so wichtig? Sie folgen nicht den uns geläufigen Mustern mit Hilfe derer wir auf Malignität schließen, d. h. kleine solide, homogene Knoten können hochmaligne und inhomogene, irreguläre Raumforderungen benigne sein: in dieser Arbeit haben sich die Autoren der Qualifikation der Weichteiltumoren in diesem Sinne gewidmet und nachgewiesen, dass es sowohl in der Sonografie (als auch vielfach korrespondierend in der MRT) besonders über die Kontrastanreicherung („CE pattern“) möglich ist mit hoher Wahrscheinlichkeit Differenzierungen durchzuführen. Die Biopsie wird somit in der Diagnostik derartiger Tumoren nicht mehr zum einzigen Mittel der Wahl für die präliminare Abklärung (z. B. vor Resektion).

\section{Arbeitsgruppe Klauser}

- Semin Musculoskelet Radiol. 2016 Nov;20(5):496 - 506.

Recommendations of the ESSR Arthritis Subcommittee on Ultrasonography in Inflammatory Joint Disease. Plagou A, Teh J, Grainger AJ, Schueller-Weidekamm C, Sudoł-Szopińska I, Rennie W, Åström G, Feydy A, Giraudo C, Guerini H, Guglielmi G, Isaac A, Jans L, Jurik AG, Kainberger F, Maas M, Martinoli C, Mascarenhas VV, Miese F, O'Connor P, Oei EH, Østergaard M, Peetrons P, Platz- 
gummer $\mathrm{H}$, Reijnierse M, Robinson P, Rupreht M, Simoni P, Wick MC, Zejden A, Klauser AS.

This article presents the recommendations of the European Society of Musculoskeletal Radiology Arthritis Subcommittee on the use of ultrasonography (US) in rheumatic disease, focused on the examination of joints in the adult population. The recommended examination technique and protocols used in a radiologic work-up are discussed. The main US features that can lead to a final diagnosis in the most common rheumatic diseases are addressed. The differential diagnosis that should be considered at image interpretation is presented. The role of US in interventional procedures and clinically important recent developments is also discussed.

- Radiographics. 2015 Nov-

Dec;35(7):2026 - 48. doi: 10.1148/

rg.2015 140250 .

High-Resolution US of Rheumatologic

Diseases.Review. Taljanovic MS, Melville

DM, Gimber LH, Scalcione LR, Miller MD, Kwoh CK, Klauser AS.

For the past 15 years, high-resolution ultrasonography (US) is being routinely and increasingly used for initial evaluation and treatment follow-up of rheumatologic diseases. This imaging technique is performed by using high-frequency linear transducers and has proved to be a powerful diagnostic tool in evaluation of articular erosions, simple and complex joint and bursal effusions, tendon sheath effusions, and synovitis, with results comparable to those of magnetic resonance imaging, excluding detection of bone marrow edema. Crystal deposition diseases including gouty arthropathy and calcium pyrophosphate deposition disease (CPPD) have characteristic appearances at US, enabling differentiation between these two diseases and from inflammatory arthropathies. Enthesopathy, which frequently accompa- nies psoriatic and reactive arthritis, also has a characteristic appearance at high-resolution US, distinguishing these two entities from other inflammatory and metabolic arthropathies. The presence of Doppler signal in examined joints, bursae, and tendon sheaths indicates active synovitis. Microbubble echo contrast agents augment detection of tissue vascularity and may act in the future as a drug delivery vehicle. Frequently, joint, tendon sheath, and bursal fluid aspirations and therapeutic injections are performed under US guidance. The authors describe the high-resolution US technique including gray-scale, color or power Doppler, and contrast agent-enhanced US that is used in evaluation of rheumatologic diseases of the wrist and hand and the ankle and foot in their routine clinical practice. This article demonstrates imaging findings of normal joints, rheumatoid arthritis, gouty arthritis, CPPD, psoriatic and reactive arthritis, and osteoarthritis.

- Radiographics. 2016 Mar-

Apr;36(2):479 - 80. doi: 10.1148/

rg.2016150200.

Artifacts at Musculoskeletal US: Resident and Fellow Education Feature. Gimber LH, Melville DM, Klauser AS, Witte RS, Arif-Tiwari H, Taljanovic MS.

Der Stellenwert der Sonoelastographie am Bewegungsapparat ist unter reger Evaluierung und konnte anhand von histologischen Korrelationen an den Flexoren und Extensorensehnenansätzen weiters untermauert werden. Es zeigt sich, dass die Kombination von B-Bild mit Elastographie zielführender ist als eine Methode alleine.

- Radiology. 2016 Dec 7:160 139. [Epub ahead of print]

Sonoelastography of the Common Flexor Tendon of the Elbow with Histologic Agreement: A Cadaveric Study. Klauser AS, Pamminger MJ, Halpern EJ, Abd Ellah MM, Moriggl B, Taljanovic MS, Deml C, Sztankay J, Klima G, Gruber L, Jaschke WR.
Purpose To determine the correlation of the results of conventional B-mode ultrasonography (US) and compression sonoelastography with histologic results in common flexor tendons of the elbow in human cadavers. Materials and Methods Twenty-five common flexor tendons were evaluated in 16 fresh, unembalmed cadavers of 11 women with a median age of 85 years (range, $71-101$ years) and five men with a median age of 78 years (range, $70-$ 88 years). Informed consent was provided according to the last will of the donors. B-mode US results were classified as grade 1 , normal tendon with homogeneous fibrillar pattern; grade 2, tendon thickening or hypoechoic areas and/or calcifications in less than $30 \%$ of the tendon; or grade 3 , hypoechoic areas and/or calcifications greater than $30 \%$ of the tendon. Sonoelastographic results were grade 1 , blue (hardest) to green (hard); grade 2, yellow (soft); and grade 3 , red (softest). The intraclass correlation coefficient was calculated to determine agreement with histologic findings for each B-mode US, sonoelastographic, and combined B-mode US and sonoelastographic examination. Histologic results were grade 1, normal, with parallel fibrillar pattern; grade 2, mild tendinopathy, with cellular infiltration, angiogenesis, or fatty vacuoles; or grade 3, severe tendinopathy, with loss of parallel collagen structure and necrosis. Results Histologic alterations were detected in $44 \%$ (11 of 25 ) of biopsy specimens. Intraclass correlation with histologic results was 0.57 for B-mode US, 0.68 for sonoelastography, and 0.84 for the combination of the two approaches. Conclusion The addition of sonoelastography to B-mode US provided statistically significant improvement in correlation with histologic results compared with the use of $\mathrm{B}$-mode US alone $(\mathrm{P}<0.02)$.

Wir wünschen viel Spass beim Lesen des einen oder anderen Artikels! 